\title{
Ripened Curd Cheese Slurries in the Manufacture of Processed Cheese
}

\author{
Aisha, M.A. El-Attar, Awad, S.A. \& El-Soda, M.A. \\ Dairy Science Dept., Fac. of Agric., Alexandria Univ., Alexandria, Egypt.
}

\begin{abstract}
The effects of Ras curd slurries in the manufacture of processed cheese on chemical, rheological and organoleptic properties were studied. Curd slurries were incorporated to provide flavour of aged cheese. Seven Ras curd slurries were prepared using lactic acid bacteria isolated from Egyptian dairy products. $\mathrm{The} \mathrm{pH}$, fat and protein contents were not affected by replacing aged cheese with curd slurries. The moisture content was found to be playing a major role in textural properties of processed cheeses. Consistency was found to be related to hardness. Sensory scores for texture and flavour of blending of young Ras cheese and cheese slurries prepared using Lb. salivarius 194KC, Lc. lactis subsp. lactis $608 \mathrm{~N}$ and Lb. salivarius $194 \mathrm{KC} \&$ Lc. lactis subsp. lactis 64RM were higher than those of the blending of aged/young Ras cheese. Cheese slurries could offer some advantages for processed cheese industries in Egypt; low production costs, improving the consistency, diverse flavour range, extended shelf- life, low storage costs and improved functionality.
\end{abstract}

Keywords: cheese slurry, processed cheese, texture, rheology, sensorial properties, moisture, protein content, pH

\section{INTRODUCTION}

Processed cheese is a generic term used to describe 3 separate categories of cheese. These categories are pasteurized processed cheese (PC), pasteurized processed cheese food (PCF) and pasteurized processed cheese spread (PCS) (Code of Federal Regulations, 2003). These categories differ on the basis of the requirements for minimum fat content, dry matter basis and the maximum allowed moisture content as well as the quality and the number of optional ingredients that can be used. The moisture content of a pasteurized processed cheese food is not more than $44 \%$, and the fat content is not less than $23 \%$.

Processed cheese is manufactured by adding water and emulsifying salt to shredded natural cheese of different types and degrees of maturity, followed by heating the blend under a partial vacuum with a constant agitation until a homogenous mass is obtained. In addition to natural cheese, other ingredients of both: dairy, (butter, cream, skimmed milk powder, whey powder) and non dairy products (ham, fish, vegetables, salt) origin may be included in the blend (Piska \& Štětina, 2004).

The addition of proper cheese is of utmost importance for the successful production of processed cheese. Processed cheese has many unique functional characteristics as compared to natural cheese. These include metability, plasticity and shelf-stability (Zehren \& Nusbaum, 1992).

The processed cheese is made from blending of aged and young cheese. The production of processed cheese in Egypt requires the consumption of imported as well as local cheeses. The imported cheeses are usually stored for long periods of time which may diminish the quality of flavour and texture. Normally, imported and local cheeses require 3 to 12 months in the maturation to produce desired physicochemical and organoleptic properties. Several efforts have been made to accelerate the processed of cheese ripening. The cost of cheese ripening is quite high, for example, the ageing time of Cheddar cheese adds significantly to product costs, ranging from $1.5 \%$ to $3.0 \%$ per month (El-Soda, 2002). Nowadays, cheese making involves high capital investment and the running costs and interest charges involved in cheese storage represent a significant proportion of the total costs. The economic advantage of rapid development of more intense cheese flavour in shorter periods of time would be substantial. Acceleration of cheese ripening can also be a means for increasing the production of cheese in developing countries where investment in storage facilities can be a limiting factor (Kilcawley et al., 1998). Rapid 
production of cheese flavour can also contribute in lowering the price of processed cheese through the incorporation of cheese slurries in the mixing blend for processed cheese (Fox et al., 2004).

Curing the homogenous slurry of unpressed curd is an attempt to accelerate the ripening of cheese. Slurry would have advantages over normally ripened cheese including acceptable flavour and texture analogous to the typical ripened cheese (Kilcawley et al., 2000). Raising the proteolysis of cheese leads to have processed cheese more meltable and softer (Awad et al., 2006a, b). Processed cheese products offer many advantages as compared to natural cheese especially in developing countries, reducing the need for refrigeration storage which makes processed cheese easier for manufacturing and storage in countries with poor refrigeration systems. Providing cheese with better keeping quality is a great advantage in developing countries where the production of natural cheeses can be a hazard (Kilcawley et al., 2000).

The blend of young cheese and the appropriate cheese slurry produces a high-quality economical processed cheese with appropriate performance characteristics and flavour. The objective of this study is the evaluation of some lactic acid bacteria isolated from Egyptian dairy products in cheese slurry to replace the aged cheese in the manufacture of processed cheese for reducing the production cost with maintaining good quality of the product.

\section{MATERIALS AND METHODS}

\section{Cultures}

Lactococcus lactis 64 RM \& 608N, Enterococcus faecium 174RM \& 151D, Lactobacillus salivarius $194 \mathrm{KC}$ and Lactobacillus rhamnosus 56R were isolated from different dairy products and identified in the Laboratory of the Biochemistry of Dairy Microorganisms, Department of Dairy Science and Technology at the Faculty of Agriculture, Alexandria University ( Table 1).

Lactococcus lactis 64 RM \& 608N, Enterococcus 174RM \& 151D were cultivated in M17 medium, while Lactobacillus 194KC \& 56R were grown in MRS medium. The optimum temperature for Lactococcus strains is $30^{\circ} \mathrm{C}$, while for the remaining tested strains is $42^{\circ} \mathrm{C}$.

Cells were harvested at early stationary phase by centrifugation at $10000 \mathrm{Xg}$ for $20 \mathrm{~min}$ at $4^{\circ} \mathrm{C}$. The pellets were then washed twice with $0.01 \mathrm{M}$ potassium phosphate buffer $\mathrm{pH} 7.0$ and stored at $-20^{\circ} \mathrm{C}$.

\section{Ingredients}

Young Ras cheese (2 months) and old Ras cheese ( 8 months) were obtained from the Dairy pilot plant at the Department of Dairy Science and Technology, Faculty of Agriculture, Alexandria University. Emulsifying salts (disodium phosphate and citric acid) were obtained from El Gomhouria Co, Alexandria, butter oil (Fern, Newzeland), skimmed milk powder (Grino, Interfood, Holland). The composition of ingredients is shown in Table (2).

\section{Preparation of processed cheese}

Seven single strains or mixtures of two strains of Lactic Acid Bacteria (LAB) isolated from Egyptian Dairy products were employed in Ras cheese slurries as described earlier (El-Attar, 2006). Table (1) shows the strains and its mixtures used in preparation the cheese slurries and their isolated sources.

The ingredient amounts to produce $5 \mathrm{~kg}$ of pasteurized processed cheese food were as follow: 2.5 $\mathrm{Kg}$ of young Ras cheese, $600 \mathrm{~g}$ of skimmed milk powder, 700g of butter oil (Fern, Newzeland), 100 $\mathrm{g}$ of ripened Ras cheese curd slurry, $500 \mathrm{ml}$ water,

Table 1: The cultures used in preparation the cheese slurries

\begin{tabular}{llc}
\hline Slurry culture & Isolated source & Treatment number \\
\hline Control & & 1 \\
Ent. faecium 174RM & Milk & 2 \\
Ent. faecium 151D & Domiati cheese & 3 \\
Lb. salivarius 194KC & Karish cheese & 4 \\
Lc. lactis sub sp. lactis 608N & Yogurt & 5 \\
Lc. lactis sub sp. lactis 64RM & Cow milk & 6 \\
Lb. salivarius 194KC \& Lc. lactis sub sp. lactis 64RM & & 7 \\
Lb. rhamnosus 56R \& Lc. lactis sub sp. lactis 608N & & 8 \\
\hline
\end{tabular}


Table 2: Chemical composition of ingredients used for processed Ras cheese making

\begin{tabular}{llll}
\hline \multicolumn{1}{c}{ Ingredients } & $\begin{array}{c}\text { Fat } \\
\mathbf{( \% )}\end{array}$ & $\begin{array}{c}\text { Moisture } \\
\mathbf{( \% )}\end{array}$ & $\begin{array}{l}\text { Salt } \\
\mathbf{( \% )}\end{array}$ \\
\hline Young Ras cheese & 29 & 41.3 & 3.7 \\
Old Ras cheese & 37 & 32.1 & 3.9 \\
Ripened Ras cheese slurry & 23.8 & 40.44 & 3.5 \\
Butter oil & 99 & 0 & 0 \\
Emulsifier & 0 & 20 & 80 \\
Skimmed milk powder & 4 & 4 & 0 \\
Added water & 0 & 100 & 0 \\
\hline
\end{tabular}

$120 \mathrm{~g}$ of emulsifying salt (disodium phosphate) and about $10 \mathrm{~g}$ of citric acid for adjusting the $\mathrm{pH}$ to $\approx$ 5.6. Since the moisture present in any cheese is not sufficient, it is necessary to add water to the reactive mixture in order to dissolve the emulsifying salt and achieve a good dispersion and complete emulsification. For that reason, $500 \mathrm{ml}$ of water were added. Also about $500 \mathrm{ml}$ water were condensed from the steam. The control processed cheese was prepared by blending $1.35 \mathrm{Kg}$ aged Ras cheese and $1.25 \mathrm{Kg}$ young Ras cheese with the remaining ingredients without adding Ras cheese curd slurry (100 g). The blend was placed in laboratory style processing kettle. The ingredients were mixed for about 30 seconds and cooked at $80^{\circ} \mathrm{C}$ for 3 min using direct steam injection. The processed cheese food was manually filled in jars $500 \mathrm{~g}$ capacity, and turned upside-down to decrease the microbial growing by reducing the air content. Each blend of processed cheese was rapidly cooled and stored at $10^{\circ} \mathrm{C} / 7$ days, two replicates were made for each batch.

\section{Chemical analysis}

Processed cheese samples were analyzed for fat and protein contents according to the AOAC, (1984). The moisture content was determined using the moisture analyzer, (Mettler Toledo Model HR73, Switzerland) and $\mathrm{pH}$ was measured on the well mixed ground cheese samples by using a glass electrode ( $\mathrm{pH}$ model 3900-010, Precisa, Switzerland). Salt content was determined using chloride meter (Jenway, England, UK).

\section{Rheological analysis}

Cheese samples were cut into cubes, each 5 $\mathrm{cm}^{3}$ and kept at $15^{\circ} \mathrm{C} / 12 \mathrm{hrs}$ before analysis. Rheological tests of processed cheese food were carried out by Texture Analyser (CNS-Farnell, England). The probe was TA 15 ( $45^{\circ}$ and $30 \mathrm{~mm}$ diameter), at speed of $1 \mathrm{~mm} / \mathrm{sec}$ and $10 \mathrm{~mm}$ distance, using cycle or hold programs. Hardness, consistency, cohesiveness, springiness, fracturability, gumminess, modulus, adhesiveness and relaxation $\%$ were calculated as described by Szczesniak et al. (1963) and Bourne (1978).

\section{Sensory evaluation}

Processed cheese samples were organoleptically evaluated according to Ayad et al. (2004) by a panel consisting of 13 persons, including staff members, assistants and students at the Department of Dairy Science and Technology, Faculty of Agriculture, University of Alexandria. The panelists judged the processed cheeses according to the following points: flavour (out of 50), texture (out of 40) and section and colour (out of 10). A list containing the acceptable description of flavour, texture, section and colour of cheese was present to aid the panelists in carrying out the sensory evaluation. Furthermore, each tested processed cheese was given an overall grade out of 100 and whether each sample was typical processed cheese or not.

\section{Statistical Analysis}

Data reported are the average of 3 measurements per replicate. The GLM procedure using SAS statistical analysis software package (SAS Institute, 1999) was used for ANOVA. Means separation was conducted using Duncan's multiple range tests. Differences were considered significant at $\mathrm{P}<0.05$.

\section{RESULTS AND DISCUSSION}

\section{Chemical composition}

Table (3) shows the chemical composition of processed cheese as affected by adding curd Ras cheese slurries (El-Attar, 2006). There were no differences among most of cheese samples in fat and salt content. The $\mathrm{pH}$ was almost similar in most of the processed cheeses. These data proved that partial substitution of Ras cheese solids with cheese slurries accompanied by standardization of fat, salt and $\mathrm{pH}$ of the blend did not affect their values in the resultant processed cheese. The control processed cheese (T1) had slightly higher salt and fat contents than the remaining examined processed cheese (with adding slurry). These results could be attributed to the high contents of fat and $\mathrm{NaCl}$ in aged Ras cheese (Table 2). Moisture contents in examined processed samples ranged from 38.21 to $43.03 \%$. These differences could be attributed to the differ- 
Table 3: Chemical composition and pH of processed cheese

\begin{tabular}{cccccc}
\hline Cheese treatments & Fat $(\%)$ & Salt $\mathbf{( \% )}$ & pH & Moisture (\%) & Protein (\%) \\
\hline T1 & $25.8 \pm 0.8$ & $1.99 \pm 0.022$ & $5.73 \pm 0.08$ & $38.67 \pm 1.1$ & $23.32 \pm 0.42$ \\
T2 & $24.1 \pm 0.9$ & $1.76 \pm 0.21$ & $5.74 \pm 0.04$ & $41.51 \pm 0.8$ & $22.21 \pm 0.56$ \\
T3 & $23.3 \pm 1.3$ & $1.76 \pm 0.25$ & $5.74 \pm 0.03$ & $39.19 \pm 1.3$ & $23.13 \pm 0.32$ \\
T4 & $24.4 \pm 1.1$ & $1.61 \pm 0.23$ & $5.89 \pm 0.07$ & $42.95 \pm 0.3$ & $21.58 \pm 0.43$ \\
T5 & $24.2 \pm 0.8$ & $1.53 \pm 0.32$ & $5.8 \pm 0.05$ & $39.72 \pm 0.7$ & $24.50 \pm 0.56$ \\
T6 & $23.4 \pm .1 .3$ & $1.65 \pm 0.23$ & $5.83 \pm 0.06$ & $40.46 \pm 0.8$ & $21.12 \pm 0.45$ \\
T7 & $25.1 \pm 0.7$ & $1.69 \pm 0.28$ & $5.75 \pm 0.07$ & $38.21 \pm 1.2$ & $23.58 \pm 0.65$ \\
T8 & $23.2 \pm 1.1$ & $1.66 \pm 0.23$ & $5.68 \pm 0.07$ & $43.03 \pm .08$ & $21.32 \pm 0.45$ \\
\hline
\end{tabular}

Values are expressed as means $\pm \mathrm{SD}$.

T1: Control cheese made from a blinding of young and aged Ras cheeses, T2: Cheese made using curd slurry with Ent. faecium 174RM, T3: Cheese made using curd slurry with Ent. faecium 151D, T4: Cheese made using curd slurry with Lb. salivarius 194KC, T5: Cheese made using curd slurry with Lc. lactis sub sp. lactis 608N, T6: Cheese made using curd slurry with Lc. lactis sub sp. lactis 64RM, T7: Cheese made using curd slurry with Lb. salivarius $194 \mathrm{KC}$ \& Lc. lactis sub sp. lactis 64RM and T8: Cheese made using curd slurry with Lb. rhamnosus 56R \& Lc. lactis sub sp. lactis $608 \mathrm{~N}$.

ences in the condensing condition in the machine during the preparation of processed cheese. The fat and protein contents were found to be related to the moisture content of the samples.

\section{Textural characteristics of processed cheese}

Hardness is a parameter for cheese quality (soft, firm, hard). Hardness is recognized as the force which is required to compress a sample between the molars.

The differences in hardness values among treatments are shown in Table 4. Since there were no differences in chemical composition and $\mathrm{pH}$ values between the control cheese made from blending 50/50 aged/young Ras cheese (T1) and the cheese made from blending of young and slurry Ras cheese (T7) (Table 3), the differences in hardness of these samples are related to protein structure and network. The structural matrix of cheese is a crosslinked casein-calcium phosphate network in which fat globules are physically entrapped (Prentice et al., 1993). The protein matrix is elastic when the casein is largely intact (Jameson, 1990). The high proteolysis in aged cheeses decreases the hardness of processed cheese control (T1) as compared to that made from blending of young and slurry Ras cheese (T7), same results were also reported by Awad et al. (2006a). The type, characteristic, age of the natural cheese and the moisture content play a major role in controlling the textural, viscoelastic, functional, microstructural and sensorial properties of processed cheese (Bowland \& Foegeding 2001, French et al., 2002, Glenn et al., 2003, Acharya \& Mistry 2005). Moreover, Awad et al., (2006a)

Table 4: Mean values of texture profile analysis of processed cheese*

\begin{tabular}{|c|c|c|c|c|c|c|c|c|c|c|}
\hline 号 & 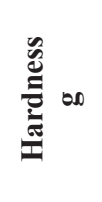 & 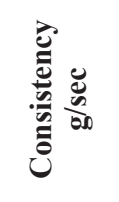 & 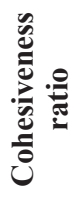 & 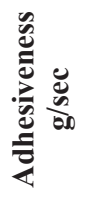 & 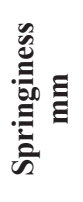 & 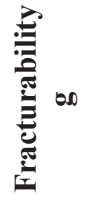 & 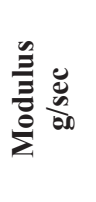 & 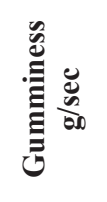 & م. & 总 \\
\hline $\mathrm{T} 1$ & 213.8 & 1746.9 & 1.9 & 79.1 & 1.2 & 36.0 & 10.3 & 406.2 & 487.5 & 37.6 \\
\hline $\mathrm{T} 2$ & 184.1 & 1515.8 & 2.1 & 59.1 & 1.0 & 33.3 & 8.8 & 386.9 & 404.2 & 36.4 \\
\hline $\mathrm{T} 3$ & 211.4 & 1682.0 & 2.1 & 62.0 & 1.1 & 39.0 & 10.1 & 442.0 & 465.5 & 38.6 \\
\hline $\mathrm{T} 4$ & 150.4 & 1231.0 & 2.1 & 64.3 & 1.1 & 34.0 & 7.1 & 321.9 & 344.5 & 33.4 \\
\hline $\mathrm{T} 5$ & 204.8 & 1645.0 & 2.2 & 60.5 & 1.1 & 34.0 & 9.9 & 451.4 & 478.1 & 38.6 \\
\hline T6 & 213.8 & 1730.0 & 1.8 & 85.6 & 1.1 & 30.0 & 10.2 & 380.7 & 410.4 & 36.9 \\
\hline $\mathrm{T} 7$ & 224.5 & 1834.2 & 1.9 & 83.1 & 1.2 & 37.8 & 10.8 & 426.6 & 511.9 & 37.1 \\
\hline T8 & 160.1 & 1368.0 & 2.0 & 57.0 & 1.0 & 30.0 & 7.6 & 327.1 & 336.6 & 34.3 \\
\hline
\end{tabular}

*average of two replicates 
reported that processed cheese made from $100 \%$ young cheese was harder than cheese made from blending aged and young Cheddar cheese, while the hardness decline in the processed cheese made from Cheddar cheese (1 month old). The decrease in hardness during the early stages of ripening is attributed to early change in the texture which is attributed to proteolysis of casein network, increasing protein hydration and solubilization of colloidal calcium phosphate (Creamer \& Olson, 1982, McMahon, et al., 1999, Guinee, 2002, Lucey et al., 2003). Water redistribution, which occurs mainly during the first few weeks of ripening (McMahon et al., 1999), seemed to play a major role in cheese softening during the first weeks of ripening.

However, the differences in hardness of processed cheese should be related partially to moisture content in the current study. The highest hardness level was found in the sample $\mathrm{T} 7$ with moisture $38.2 \%$, while the lowest hardness was in the sample T4 (42.95\% moisture). Slight differences in moisture of processed cheese may cause major differences in its rheological parameters, slight higher moisture content in the sample T2 $(41.5 \%)$ as compared to the sample $\mathrm{T} 6(40.5 \%)$ radically reduced the hardness by about $13 \%$.

Consistency is the internal strength of bonds within a product, it is the total positive area of the first bite. Consistency was found to be related to hardness, so, the consistency is higher in the hard samples than in the soft samples.

Cohesiveness is the strength of internal bonds making up the body of the product, it is the ratio of the positive area during the second compression to that during the first compression.

The cohesiveness seems to be related to protein content in processed cheese. It is clear that cohesiveness was higher in the processed cheese $\mathrm{T} 5$ than in the cheese T6 (Table 4), the protein content of which is higher than in cheese T6 (Table 3). Meanwhile, the cohesiveness was lower in the control cheese $\mathrm{T} 1$ than in $\mathrm{T} 3$ with similar protein content, these related to the higher proteolysis in control cheese made from aged cheese. The nature and the content of the protein matrix and the extent of fat dispersion contribute to cohesiveness or the tendency of cheese to adhere to itself. Proteolysis disrupts the structural integrity of the protein matrix, leading to reduced cohesiveness (Irudayaraj et al., 1999).

Adhesiveness is recognized as the work required to overcome attractive forces between sur- face of the cheese and surface of other materials with which the cheese comes into contact. There was a difference in adhesiveness of processed cheeses, it was not found to be related to moisture content or to hardness. The highest adhesiveness value was observed in the cheese T6 and the lowest adhesiveness was in the cheese T8 which contained high moisture content as compared to cheese T6. On the other hand, cheeses T5 and T6 had slight differences in moisture content, and the cheese T6 recorded significantly higher value of adhesiveness than the cheese T5.

Springiness is the rate at which a deformed material returns to its original shape on removal of deforming force. The height that the cheese recovers during the time elapsed between the end of the first bite and the start of the second is taken as springiness.

The springiness exhibited a slight difference among all treatments except the cheeses numbers $\mathrm{T} 1$ and T7. These results indicated that the ability of the processed cheese to recover its original height after removing the force is almost similar. Springiness was much higher in cheeses T1 and T7 than in all the other cheeses (Table 4).

Fracturability is the force at which the sample or material fractures, it is the first significant break in the first compression cycle. The fracturability values were higher in low moisture content cheeses (T3 and T7) than in high moisture content cheeses (T8). The fracturability values were also related partially to proteolysis in base cheese as the fracturability was lower in control cheese T1 as compared to $\mathrm{T} 7$ with similar moisture content.

Modulus is the ratio of sample stress divided by strain during the first compression cycle e.g. the slope of force, deformation curve within linear region. It is a representative of sample rigidity. There was a positive relationship between the consistency and modulus. Replacing aged cheese with cheese slurries and young cheese slightly increased the rigidity of processed cheeses. Since viscoelastic moduli are proportional to the number of bonds formed in the gel network (Lucey et al., 2003), it could be assumed that the processed cheeses T4 and $\mathrm{T} 8 \mathrm{had}$ less tight network structure than the cheeses $\mathrm{T} 6$ and $\mathrm{T} 7$.

Gumminess is the energy required to disintegrate a semi -solid food for swallowing calculated parameter: Hardness $\times$ Cohesiveness. The gumminess in processed cheese was found to be related to 
moisture content and hardness. The cheese samples T3 and T7 recorded higher values for hardness and gumminess as compared to the samples T4 and T8.

The results of Chewiness shown in Table (4) indicate that the energy required to masticate the cheese product to a state ready for swallowing 'Chewiness' is higher in the processed cheese T7. The same trend was also noticed for the energy required to disintegrate the cheese product 'gumminess'.

Chewiness was not found to be related to the hardness. Chewiness was higher in the cheese T1 as compared to the cheese T6, whereas these both cheeses were similar in hardness. These indicated that the texture properties of processed cheese are related to many factors (i.e. moisture, $\mathrm{pH}$, protein structure, fat content, salt content and protein content).

Relaxation curves are used to demonstrate the visco-elastic properties of solid foods (Peleg, 1979). Stress relaxation experiments involve the compression of a sample to a target distance. The relaxation \% was higher in low moisture cheeses (T1, T3 and T7) as compared to higher moisture cheeses (T4 and T8), same results were reported in Talaga cheese by Awad et al. (2002). Stress relaxation experiments involve the compression of a sample to a target distance. The sample remains compressed at this distance for a target period of time during which the load response of the sample is recorded by the texture analyser i.e. the apparatus records the subsequent decrease in load as the sample relaxes under constant deformation. The general rule is that the greater the viscous component of the sample the greater the relaxation. Elastic materials relax much less at a considerably slower rate. Therefore, the greater the $\%$ the lower the relaxation and the increased elastic component and/or resistance of internal structure to fracture.

\section{Sensorial quality}

Eight tested processed cheeses made from different types of aseptic curd Ras cheese slurries (E1Attar, 2006) were assessed organoleptically. The results are presented in Table (5). The cheeses T4, T5 and $\mathrm{T} 7$ have received significantly higher scores for acceptable flavour as compared to the control. Conversely, the unacceptable tested processed cheeses were noticed in samples T2, T3 and T8. The cheese T7 gained the significantly highest score followed closely by T5 and T4 $(91.5,89.6$, and 87.7 , respectively). Whereas, the control (T1) has a sensory score approach to the blend containing Lc. lactis sub sp. lactis 64RM strain (79.3 and 77, respectively). So, the slurries containing Lb. salivarius $194 \mathrm{KC} \&$ Lc. lactis sub sp. lactis 64RM and Lc. lactis sub sp. lactis $608 \mathrm{~N}$ could improve the texture as well as the flavour of cheese compared with the control (Table 5 ). This result could be attributed to the high proteolytic activity of Lb. salivarius $194 \mathrm{KC}$ and Lc. lactis sub sp. lactis $608 \mathrm{~N}$ and subsequently high contents of protein (Table 3 ).

As shown in (Table 5), flavour score in both cheeses T7 and T4 exhibited significantly the highest values (45 and 45.7 points, respectively), whereas for the control gained only 33.6 points for the same character. The obtained result indicates that using rapidly ripened cheese improved the quality of resultant processed cheese, this result was in agreement with El-Neshawy et al. (1987). The texture of cheeses T7 and T5 was firm and that is suitable for the consumers of processed cheese. The section and colour score of control processed cheeses was significantly the highest compared to the other tested

Table 5: Mean values of sensory evaluation of processed cheese

\begin{tabular}{|c|c|c|c|c|}
\hline Samples & $\begin{array}{l}\text { Flavour } \\
\text { (50) }\end{array}$ & $\begin{array}{l}\text { Texture } \\
\text { (40) }\end{array}$ & $\begin{array}{c}\text { Section and colour } \\
\text { (10) }\end{array}$ & $\begin{array}{c}\text { Total Score } \\
\text { (100) }\end{array}$ \\
\hline $\mathrm{T} 1$ & $33.6 \mathrm{bc}$ & $35.7 \mathrm{ab}$ & $10.0^{\mathrm{a}}$ & $79.3 \mathrm{~b}$ \\
\hline $\mathrm{T} 2$ & $31.7 \mathrm{c}$ & $33.3^{b}$ & $8.3^{\mathrm{a}}$ & $73.3^{c}$ \\
\hline $\mathrm{T} 3$ & $37.1^{b}$ & $30.0^{\mathrm{c}}$ & $8.3^{a}$ & $76.2 \mathrm{bc}$ \\
\hline $\mathrm{T} 4$ & $45.7^{a}$ & $32.9 b c$ & $9.1^{\mathrm{a}}$ & $87.7 \mathrm{a}$ \\
\hline $\mathrm{T} 5$ & $44.4 \mathrm{a}$ & $36.3 \mathrm{a}$ & $9.0^{\mathrm{a}}$ & $89.6^{a}$ \\
\hline T6 & $36.9 \mathrm{~b}$ & $31.3^{b}$ & $8.5^{\mathrm{a}}$ & $77.0^{\mathrm{b}}$ \\
\hline $\mathrm{T} 7$ & $45.0^{\mathrm{a}}$ & $37.5^{\mathrm{a}}$ & $9.0^{\mathrm{a}}$ & $91.5^{\mathrm{a}}$ \\
\hline $\mathrm{T} 8$ & $33.6 \mathrm{bc}$ & $31.4 \mathrm{bc}$ & $6.9 \mathrm{~b}$ & $71.9 \mathrm{c}$ \\
\hline
\end{tabular}

Means in a column not sharing the same letter are significantly different at $\mathrm{P}<0.05$. 
samples, additionally, samples T7 and T5 showed a similar score (9), these samples have closed and regular section and colour.

On the other hand, processed cheese containing Lb. rhamnosus 56R \& Lc. lactis sub sp. lactis $608 \mathrm{~N}$ (T8) received the significant lowest score (6.9 points). The flavour of that cheese is described in general as unclean, soapy and salty. These flavours are mentioned as off- flavours in cheese (Law, 1982, Ogden, 1993 \& Fox et al., 1995). The evaluator's scores were in agreement with the data recorded by texture analyzer. The section of cheese T3 was irregular with a speckled colour.

\section{REFRENCES}

Acharya, M.R. \& Mistry, V.V. 2005. Effect of vacuum condensed or ultrafiltered milk on pasteurized processed cheese. Journal of Dairy Science, 88: 3037-3043.

AOAC. 1984. Official Methods of Analysis, 14th edition, Association of Official Analytical Chemists International : Washington, DC.

Awad, S., Hassan, A. N. \& Mistry, V. 2006a. Substituting aged cheese with exopolysaccharide-containing base cheese in making processed cheese. Journal of Dairy Science. 89: Supplemet I: 314.

Awad, S., Hassan, A. N. \& Mistry, V. 2006b. Impact of exopolysaccharide-containing base cheese on characteristics of reduced fat processed cheese. Journal of Dairy Science. 89: Supplemet I: 314.

Awad, S., El-Attar, A., Ahmed, N. \& El-Soda, M. 2002. Proteolysis and texture changes during the ripening of white soft cheese (Talaga). 1st Arab Mansoura Conference for Food and Dairy Science \& Technology (1-3 October. 2002). Mansoura, Egypt.

Ayad, E., Awad, S., El Attar, A., de Jong, C. \& El Soda, M. 2004. Characterisation of Egyptian Ras cheese. 2. Flavour formation. Food Chemistry. 86: 553-561.

Bourne, M. 1978. Texture profile analysis. Food Technology. 32: 62-66.

Bowland, E.L. \& Foegeding, E.A. 2001. Small strain oscillatory shear and microstructural analyses of a model processed cheese. Journal of Dairy Science. 84: 2372-2380.

Code of Federal Regulations. 2003. Section 133.169 US Dept. Health Human Services, Washington, DC.
Creamer, L.K. \& Olson, N.F. 1982. Rheological evaluation of maturing Cheddar cheese. Journal of Food Science. 62: 901-907.

El-Neshawy, A.A., Abdel Baky, A.A., Farahat S.M. \& El-Desoki, M.E. 1987. Cheese curd slurry in the manufacture of processed cheese spread. Egyptian Journal of Dairy Science. 15: 287-297.

EL Attar, A. 2006. Studies on aseptic Ras cheese slurry. Mansoura University Journal of Agriculture Science. 31: 6202- 6211.

El Soda, M. 2002. Accelerated cheese ripening. Pages 327-329 in Encyclopedia of Dairy Science. H. Roginski, J.W. Fuquay, and P.F. Fox, ed. Academic Press, London, UK.

Fox, P.F., McSweeney, P., Cogan, T. \& Guinee, T. 2004. Cheese: Chemistry, Physics and Microbiology. Third Ed., V2. Elsevier, Academic Press.

Fox, P.F., Singh, T.K. \& McSweeney, P.L.H. 1995. Biogenesis of flavour compounds in cheese. In E. L. Malin and M. H. Tunick (Eds). Chemistry of Structurelfunction Relationships in Cheese (pp. 59-98). New York: Plenum.

French, S.J., Lee, K.M., Decastro, M. \& Harper, W.J. 2002. Effects of different protein concentrates and emulsifying salt conditions on the characteristics of a processed cheese product. Milchwissenshaft, 57: 79-82.

Glenn, T.A., Daubert, III, C.R., Farkas, B.E. \& Stefanski, L.A. 2003. A statistical analysis of creaming variables impacting processed cheese melt quality. Journal of Food Quality, 26: 299-321.

Guinee, T.P. 2002. Cheese Rheology. In Roginski, H., Fuquay, J.W., \& Fox, P.F. (Eds.), Encyclopedia of Dairy Science, (pp. 341-349). London, UK: Academic Press.

Irudayaraj, J., Chen, M. \& McMahon, D.I. 1999. Texture development in Cheddar cheese during ripening. Canadian Agriculture Engineering, 41: 253-258.

Jameson, M.E. 1990. Cheese with less fat. Australian Journal of Dairy Technology, 11: 93- 98.

Kilcawley, K.N., Wilkinson, M.G. \& Fox, P.F. 1998. Enzyme-modified cheese. International Dairy Journal, 8: 1-10.

Kilcawley, K.N., M.G. Wilkinson \& P.F. Fox 2000. A survey of the composition and proteolyt- 
ic indices of commercial enzyme-modified Cheddar cheese. International Dairy Journal, 10: 181-190.

Law, B.A. 1982. Cheeses. In A. H. Rose (Ed.), Economic Microbiology : Fermented Foods. Vol 7, pp. 147. London: Academic Press.

Lucey, J.A., Johnson, M.E. \& Horne, D.S. 2003. Perspectives on the basis of the rheology and texture properties of cheese. Journal of Dairy Science, 86: 2725-2743.

McMahon, D.C., Fife, R.L. \& Oberg, C.J. 1999. Water partitioning in Mozzarella cheese and its relationship to cheeses meltability. Journal of Dairy Science, 82: 1361-1369.

Ogden, L.V. 1993. Sensory evaluation of dairy products. In Y. H. Hui (ed.), Dairy Science and Technology Hand Book. 1. Principles and Properties, pp. 157-276. New York : $\mathrm{VCH}$.

Peleg, M. 1979. Characterisation of the stress relaxation curves of solid foods. Journal of Food Science, 44: 277-281.
Piska, I. \& Štětina, J. 2004. Influence of cheese ripening and rate of cooling of the processed cheese mixture on rheological properties of processed cheese. Journal of Food Engineering, 61: 551-555.

Prentice, J.H., Langley, K.R., \& Marshall, R.J. 1993. Cheese rheology. In P.F. Fox (ed), Cheese: Chemistry, Physics, and Microbiology, Vol. 1, (pp 303-640). London, UK: Chapman \& Hall.

SAS, 1999. User's Guide: Statistics, Version 8 Edition. SAS Inst., Inc., Cary, NC.

Szczesniak, A., Brandt, M. \& Freiman, H. 1963. Development of standard rating scales for mechanical parameters and correlation between the objective and sensory texture measurements. Food Technology, 22: 50-54.

Zehren, V.L. \& Nusbaum, D.D. 1992. History of cheese making. Ch. In processed Cheese, Cheese Reporter Publishing Co., Inc., Madison, WI.

\section{استخدام معلق خثرة الجبن المسوى في صناعة الجبن المطبوخ}

$$
\begin{aligned}
& \text { عيشة محمد عبد المقصود العطار، سامح علي عوض، مرسي أبو السعود السودة }
\end{aligned}
$$

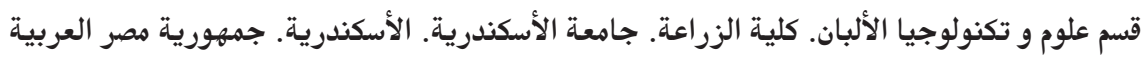

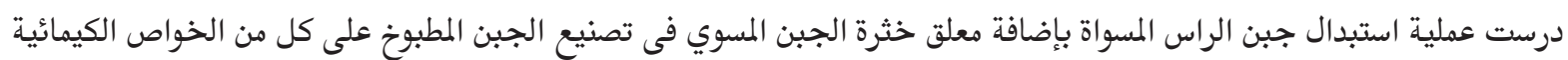

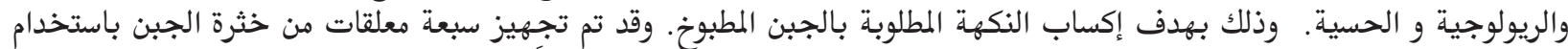

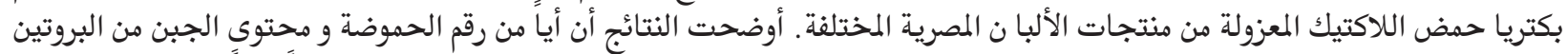

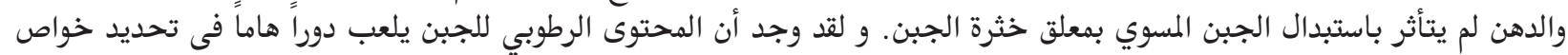

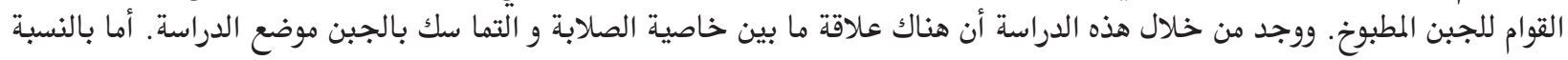

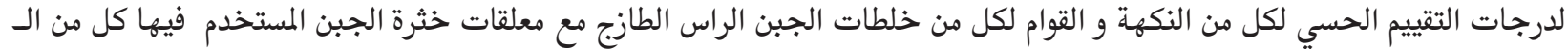

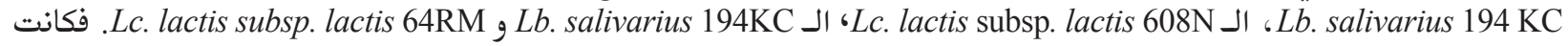

$$
\text { أعلي من الجبن الكونترول (الناتج من خلط الجبن الراس الطازج والمسوي). }
$$

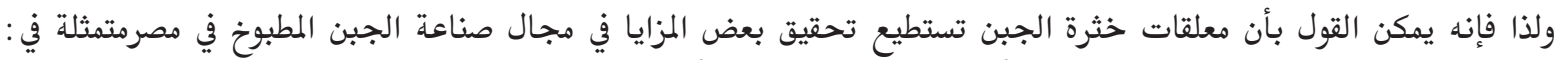

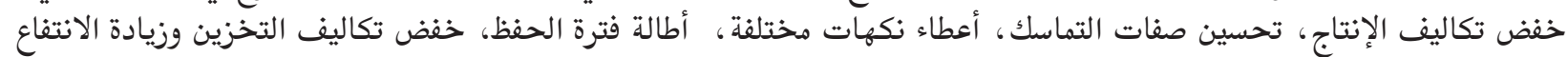
من الجبن. 